\title{
Ultrastructural comparison of Bonamia spp. (Haplosporidia) infecting ostreid oysters
}

\author{
P. M. Hine ${ }^{1,6, *}$, R. B. Carnegie ${ }^{2}$, M. A. Kroeck ${ }^{3}$, A. Villalba ${ }^{4}$, M. Y. Engelsma ${ }^{5}$, \\ E. M. Burreson ${ }^{2}$ \\ ${ }^{1}$ Investigation and Diagnostic Centre, Biosecurity New Zealand, PO Box 40-742, Upper Hutt 6007, New Zealand \\ ${ }^{2}$ Virginia Institute of Marine Science, College of William \& Mary, PO Box 1346, Gloucester Point, Virginia 23062, USA \\ ${ }^{3}$ LABPAT-IBMP (L 709), Instituto de Biología Marina y Pesquera 'Alte. Storni', Universidad Nacional del Comahue (8520), \\ San Antonio Oeste, Rio Negro, Argentina \\ ${ }^{4}$ Centro de Investigacións Mariñas, Consellería do Medio Rural e do Mar, Xunta de Galicia, Aptdo. 13, \\ 36620 Vilanova de Arousa, Spain \\ ${ }^{5}$ Central Veterinary Institute of Wageningen UR, PO Box 65, 8200 AB Lelystad, The Netherlands \\ ${ }^{6}$ Present address: 73, rue de la Fée au Bois, 17450 Fouras, France
}

\begin{abstract}
The ultrastructure of Bonamia from Ostrea angasi from Australia, Crassostrea ariakensis from the USA, O. puelchana from Argentina and O. edulis from Spain was compared with described Bonamia spp. All appear conspecific with B. exitiosa. The Bonamia sp. from Chile had similarities to the type $B$. exitiosa from New Zealand (NZ), but less so than the other forms recognized as $B$. exitiosa. Two groups of ultrastructural features were identified; those associated with metabolism (mitochondrial profiles, lipid droplets and endoplasmic reticulum), and those associated with haplosporogenesis (Golgi, indentations in the nuclear surface, the putative trans-Golgi network, perinuclear granular material and haplosporosome-like bodies). Metabolic features were regarded as having little taxonomic value, and as the process of haplosporogenesis is not understood, only haplosporosome shape and size may be of taxonomic value. However, the uninucleate stages of spore-forming haplosporidians are poorly known and may be confused with Bonamia spp. uni-nucleate stages. The many forms of NZ B. exitiosa have not been observed in other hosts, which may indicate that it has a plastic life cycle. Although there are similarities between NZ B. exitiosa and Chilean Bonamia in the development of a larger uni-nucleate stage and the occurrence of cylindrical confronting cisternae, the clarification of the identity of Chilean Bonamia must await molecular studies.
\end{abstract}

KEY WORDS: Review $\cdot$ Bonamia spp. $\cdot$ Haplosporidians $\cdot$ Ultrastructure $\cdot$ Taxonomy

\section{INTRODUCTION}

Bonamia spp., of the Phylum Haplosporidia, are obligate intrahaemocytic protistan parasites, primarily of ostreid oysters (Carnegie \& Cochennec-Laureau 2004, Engelsma et al. 2014, this DAO Special). Four species have been described. B. ostreae infects Ostrea edulis (Pichot et al. 1979), and possibly $O$. angasi (see Bougrier et al. 1986), O. chilensis (see Grizel et al. 1983) and O. puelchana (see Pascual et al. 1991). It may also infect Crassostrea spp. (Carnegie \& Cochennec-Laureau 2004), and C. gigas may act as a reservoir for B. ostreae (see Lynch et al. 2010). It is reported from $O$. edulis in Atlantic and Mediterranean Europe, Morocco (A. Villalba pers. obs.; http://web.oie.int/eng/ info/hebdo/AIS_43.HTM\#Sec2), and western (Elston et al. 1986, Friedman et al. 1989, Marty et al. 2006) and eastern (Friedman \& Perkins 1994) North America. 
It is an internationally notifiable OIE-listed pathogen. Bonamia (syn. Mikrocytos) roughleyi was described from Saccostrea glomerata (syn. commercialis) from Australia (Farley et al. 1988, Cochennec-Laureau et al. 2003), but has not been subsequently isolated and its validity as a Bonamia species is doubtful (Hill et al. 2010, Carnegie et al. 2014).

$B$. exitiosa (syn. exitiosus) infects $O$. (syn. Tiostrea) chilensis (Hine et al. 2001, Berthe \& Hine 2003) in New Zealand (NZ), O. angasi (see Corbeil et al. 2006) in Australia, O. puelchana in Argentina (Kroeck \& Montes 2005, Kroeck et al. 2008, Kroeck 2010), O. edulis off the Atlantic (Abollo et al. 2008) and the Mediterranean (Narcisi et al. 2010) coasts of Europe and O. stentina in Tunisia (Hill et al. 2010), North and South Carolina (USA), NZ and Argentina (Hill et al. 2010). It also occurs in C. ariakensis at a port in North Carolina, into which it could conceivably have been introduced from Australia by shipping (Burreson et al. 2004, Bishop et al. 2006). Like B. ostreae, it is an OIE-listed and internationally notifiable pathogen. $B$. perspora infects O. (syn. Ostreola) stentina (syn. equestris) in the southeastern USA and differs from all other reported Bonamia spp. in having a spore stage (Carnegie et al. 2006). B. exitiosa-like isolates have been reported from $O$. chilensis in Chile (Balseiro et al. 2006, Campalans \& Lohrmann 2009, Lohrmann et al. 2009).

Bonamia spp. have different patterns of development, and of developmental stages. B. perspora appears to have very few uni-nucleate, bi-nucleate, diplokaryotic and small multi-nucleate plasmodial vegetative stages. Plasmodia develop into sporonts, sporoblasts, sporocysts and spores, as do Haplosporidium spp. and Minchinia spp. (Carnegie et al. 2006). NZ B. exitiosa has many uni-nucleate, fewer bi-nucleate and diplokaryotic stages and no sporulation stages, and many uni-nucleate cells grow into large forms (Hine 1991a, Hine et al. 2001). Chilean Bonamia sp. is similar to $B$. exitiosa in developing large uni-nucleate stages during winter, but bi-nucleate stages are rare and multi-nucleate plasmodia unreported (Lohrmann et al. 2009). B. ostreae has dense and light forms of the uni-nucleate stage, which may become bi-nucleate or rarely diplokaryotic (Pichot et al. 1979), but plasmodia are small and very rarely encountered. Large plasmodia reported from $O$. edulis (Brehélin et al. 1982, Vivarès et al. 1982, Bonami et al. 1985) at one site in Brittany were probably vegetative stages of $H$. armoricanum. Therefore, initial uninucleate stages may be directly compared, but the development of large uni-nucleate forms in $B$. exitiosa and the Chilean Bonamia may not be directly compa- rable with the uni-nucleate forms of $B$. perspora and $B$. ostreae. There are also 2 forms of bi-nucleate cell: those with separated nuclei after karyokinesis and before cytokinesis, common in B. ostreae (see Balouet et al. 1983); and those with 2 apposed nuclei in a diplokaryon, which are common in B. perspora (Carnegie et al. 2006) and B. exitiosa (Hine 1991a, Hine et al. 2001), but rare in B. ostreae (Pichot et al. 1979).

For brevity, the ultrastructures of published Bonamia spp. will not be illustrated here as they are already well illustrated (Pichot et al. 1979, Hine et al. 2001, Carnegie et al. 2006, Lohrmann et al. 2009). Also, previous studies nicely illustrate important features in this study, such as nuclear membrane-bound Golgi (NM-BG), indentations in the nuclear surface (INS), perinuclear granular material, a reticulated structure which is the trans-Golgi network (TGN) and haplosporosome-like bodies (H-LBs) (Hine 1991a, 1992, Hine \& Wesney 1994a, Hine et al. 2001). Here we compared B. exitiosa from C. ariakensis on the US east coast, $O$. puelchana in Argentina and $O$. edulis in Spain, and considered what features permit their discrimination from other Bonamia species. Initially in this study, all cellular features were recorded, but subsequent analysis of nuclear shape, size and endoplasmic reticulum failed to show any patterns and are therefore not included herein.

\section{MATERIALS AND METHODS}

The fixation and processing of tissues infected with Bonamia spp. for transmission electron microscopy (TEM) has been reported for B. exitiosa (Hine et al. 2001), B. perspora (Carnegie et al. 2006) and Chilean Bonamia sp. (Lohrmann et al. 2009). It should be noted that there was variation in methods of fixation and processing, particularly the use of reduced osmium tetroxide $\left(\mathrm{OsO}_{4}\right)$ instead of normal $\mathrm{OsO}_{4}$ in the Chilean study, which enhanced membranes, possibly making NM-BG more apparent. The oysters infected with $B$. ostreae in our study were sampled from Lake Grevelingen, The Netherlands, and fixed for $1 \mathrm{~h}$ in $2.5 \%$ glutaraldehyde in $0.22 \mu \mathrm{m}$ filtered seawater (FSW), washed $2 \times$ in FSW, post-fixed for $1 \mathrm{~h}$ in $1 \%$ $\mathrm{OsO}_{4}$, stained en bloc with $5 \%$ uranyl acetate in $0.1 \mathrm{M}$ sodium acetate for $45 \mathrm{~min}$, dehydrated through 50 to $100 \%$ ethanol, cut and stained with 5\% uranyl acetate for $10 \mathrm{~min}$ and $5 \%$ lead citrate for 5 to $6 \mathrm{~min}$.

Ostrea puelchana infected with $B$. exitiosa were sampled from San Matias Gulf, northern Patagonia, Argentina. Hearts were fixed for $1 \mathrm{~h}$ in $2.5 \%$ glutaraldehyde in $0.45 \mu \mathrm{m}$ FSW and washed $3 \times$ in FSW, 
post-fixed in $1 \% \mathrm{OsO}_{4}$ buffered with $0.1 \mathrm{M}$ sodium cacodylate at $\mathrm{pH} 7.2$, dehydrated through a graded ethanol series including en bloc staining with $1 \%$ uranyl acetate at the $70 \%$ ethanol stage, and embedded in Spurr's resin. Ultrathin $(\sim 90 \mathrm{~nm})$ sections were mounted on carbon-stabilised formvar-coated 1-hole grids, stained with Reynold's lead citrate, and examined on a Zeiss CEM 902 TEM. Crassostrea ariakensis infected with $B$. exitiosa from North Carolina (USA) were processed following methods used earlier for observation of $B$. perspora (Carnegie et al. 2006) and examined on a Zeiss CEM 902 TEM.

The measurements given are from sections through the centre of the cell in which the bilaminar nuclear and plasma membranes are clearly defined. Cell size, nuclear size and the size of haplosporosomes given in the following tables were calculated as the means of the longest dimension multiplied by the dimension at right angles to it. The nucleus:cytoplasmic ( $\mathrm{N}: \mathrm{C})$ ratio was the mean of nuclear dimensions expressed as a percentage of the mean size of the cell. The term 'multi-nucleate' is used for cells with more than 2 nuclei, rather than 'plasmodium', which is reserved for a pre-sporulation stage.

\section{RESULTS}

All Bonamia spp. occurred as uni-nucleate and binucleate forms, and a multi-nucleate stage may occur in all species but was not encountered because of rarity. NZ B. exitiosa and B. perspora also have a diplokaryotic stage. TEM observations on moribund $B$. roughleyi showed a multi-nucleate stage (Cochennec-Laureau et al. 2003) that appeared to undergo schizogony to form the uni-nucleate stage, unlike Bonamia spp. and other known haplosporidians (P. M. Hine pers. obs.), suggesting that it may not be a Bonamia species.

Uni-nucleate B. exitiosa from Ostrea angasi in Australia, Crassostrea ariakensis from the eastern USA (Fig. 1B), O. puelchana from Argentina, and Spanish O. edulis (Fig. 1A) (Table 1) resemble NZ 'type' B. exitiosa (Table 2), being larger than B. ostreae (Fig. 2), with smaller haplosporosomes, and slightly larger than Chilean Bonamia, with larger haplosporosomes. Haplosporogenesis was less often observed in B. exitiosa from $C$. ariakensis than in other species (Table 1), except $B$. ostreae (Table 2). The uni-nucleate stage of $B$. perspora was larger but with smaller chromosomes (Table 2) (Fig. 3A) than the other Bonamia spp., with subsequent multi-nucleate plasmodia (Fig. 3B) developing into spores (Fig. 4). Few data were available on

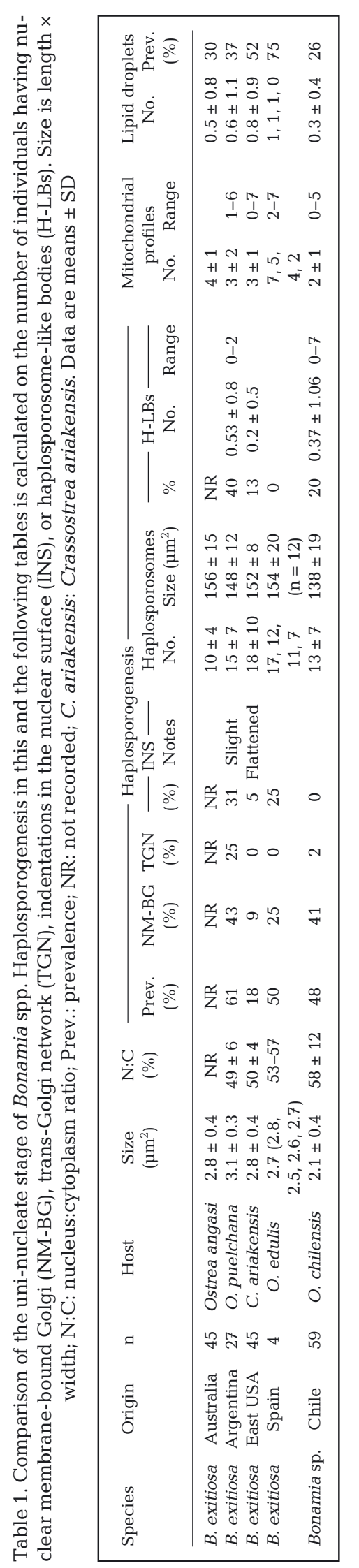

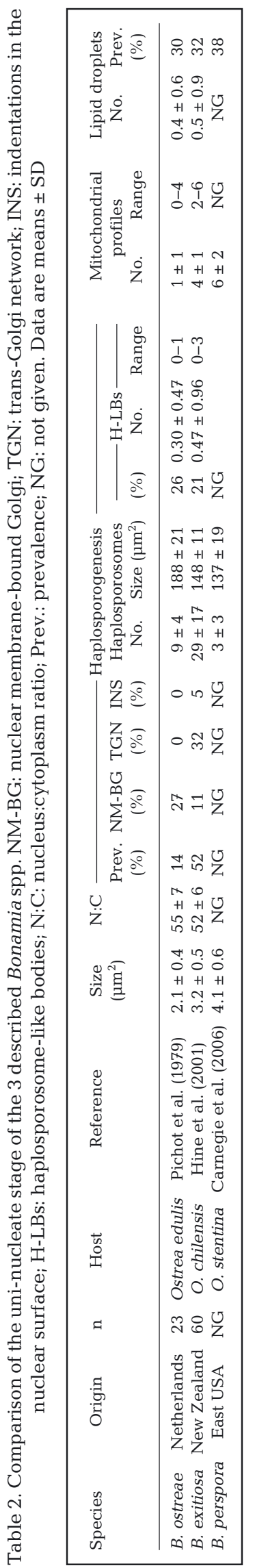


Table 3. Comparison of bi-nucleate and diplokaryotic stages of Bonamia spp. NM-BG: nuclear membrane-bound Golgi; TGN: trans-Golgi network; INS: indentations in the nuclear surface; H-LBs: haplosporosome-like bodies; N:C: nucleus:cytoplasm ratio; Prev.: prevalence

\begin{tabular}{|c|c|c|c|c|c|c|c|c|c|c|c|c|c|c|}
\hline \multirow{2}{*}{ Species } & \multirow[t]{2}{*}{ Origin } & \multirow[t]{2}{*}{$\mathrm{n}$} & \multirow[t]{2}{*}{ Stage } & \multirow{2}{*}{$\begin{array}{l}\text { Size } \\
\left(\mu \mathrm{m}^{2}\right)\end{array}$} & \multirow{2}{*}{$\begin{array}{l}\mathrm{N}: \mathrm{C} \\
(\%)\end{array}$} & \multirow{2}{*}{$\begin{array}{c} \\
\text { Prev. } \\
(\%)\end{array}$} & \multicolumn{5}{|c|}{ Haplosporogenesis - } & \multirow{2}{*}{$\begin{array}{l}\text { Mitochondrial } \\
\text { profiles }\end{array}$} & \multicolumn{2}{|c|}{ Lipid droplets } \\
\hline & & & & & & & $\begin{array}{c}\text { NM-BG } \\
(\%)\end{array}$ & $\begin{array}{c}\text { TGN } \\
(\%)\end{array}$ & $\begin{array}{l}\text { INS } \\
(\%)\end{array}$ & $\begin{array}{l}\text { No. of haplo- } \\
\text { sporosomes }\end{array}$ & H-LBs & & No. & $\begin{array}{c}\text { Prev. } \\
(\%)\end{array}$ \\
\hline B. exitiosa & New Zealand & 5 & Diplokaryon & $3.5-3.9$ & $81-86$ & 100 & 40 & 20 & 20 & $13-37$ & $0-1$ & $2-6$ & $0-2$ & 40 \\
\hline B. exitiosa & Argentina & 5 & Bi-nucleate & $3.5-3.9$ & $73-76$ & 40 & 20 & 0 & 0 & $11-46$ & $0-2$ & $4-6$ & 0 & 0 \\
\hline B. exitiosa & East USA & 3 & Bi-nucleate & $2.6-3.4$ & $60-79$ & 33 & 0 & 0 & 0 & Too few & $0-1$ & $3-5$ & $0-1$ & 33 \\
\hline Bonamia sp. & . Chile & 6 & Bi-nucleate & $2.4-3.7$ & $75-92$ & 33 & 17 & 0 & 0 & $13-27$ & $0-1$ & $2-4$ & $0-1$ & 67 \\
\hline B. ostreae & Netherlands & 5 & Bi-nucleate & $2.0-2.6$ & $84-94$ & 40 & 20 & 0 & 0 & $3-13$ & $0-1$ & $1-2$ & $0-1$ & 20 \\
\hline
\end{tabular}

Table 4. Comparison of ultrastructural features of Bonamia spp. in relation to size groups. Data are means \pm SD. Prev.: prevalence

\begin{tabular}{|c|c|c|c|c|c|}
\hline \multirow{2}{*}{$\begin{array}{l}\text { Size } \\
\text { group } \\
(\mu \mathrm{m})\end{array}$} & \multicolumn{2}{|c|}{ Haplosporogenesis } & \multirow{2}{*}{$\begin{array}{l}\text { Mitochondrial } \\
\text { profiles }\end{array}$} & \multicolumn{2}{|c|}{ Lipid droplets } \\
\hline & $\begin{array}{c}\text { Prev. } \\
(\%)\end{array}$ & $\begin{array}{l}\text { No. of haplo- } \\
\text { sporosomes }\end{array}$ & & No. & $\begin{array}{c}\text { Prev. } \\
(\%)\end{array}$ \\
\hline \multicolumn{6}{|c|}{ B. exitiosa from New Zealand } \\
\hline $2.6-3.0$ & 40 & $30 \pm 21$ & $4.4 \pm 0.9$ & $0.4 \pm 0.9$ & 20 \\
\hline $3.1-4.0$ & 56 & $27 \pm 14$ & $4.0 \pm 1.3$ & $0.7 \pm 0.9$ & 40 \\
\hline $4.1-5.0$ & 82 & $63 \pm 23$ & $8.2 \pm 4.6$ & $1.3 \pm 1.4$ & 73 \\
\hline \multicolumn{6}{|c|}{ B. exitiosa from Argentina } \\
\hline $2.6-3.0$ & 71 & $14 \pm 4$ & $4 \pm 1$ & $0.3 \pm 0.7$ & 25 \\
\hline $3.1-4.0$ & 50 & $19 \pm 10$ & $4 \pm 1$ & $0.5 \pm 1.2$ & 25 \\
\hline \multicolumn{6}{|c|}{ B. exitiosa from Crassostrea ariakensis } \\
\hline $2.1-2.5$ & 17 & $17 \pm 8$ & $1.8 \pm 1.0$ & $0.6 \pm 0.7$ & 39 \\
\hline $2.6-3.0$ & 9 & $18 \pm 10$ & $3.1 \pm 1.2$ & $0.9 \pm 1.0$ & 59 \\
\hline $3.1-4.0$ & 0 & $11 \pm 6$ & $5.2 \pm 1.1$ & $1.4 \pm 1.3$ & 80 \\
\hline \multicolumn{6}{|c|}{ Bonamia sp. from Chile } \\
\hline $1.6-2.0$ & 55 & $11 \pm 7$ & $1.8 \pm 1.3$ & $0.2 \pm 0.4$ & 16 \\
\hline $2.1-2.5$ & 38 & $12 \pm 5$ & $1.9 \pm 1.0$ & $0.3 \pm 0.5$ & 33 \\
\hline $2.6-3.0$ & 100 & $20 \pm 4$ & $2.5 \pm 1.7$ & $1 / 2=0.5$ & 50 \\
\hline \multicolumn{6}{|c|}{ B. ostreae } \\
\hline $1.6-2.0$ & 27 & $7.7 \pm 3.0$ & $1.3 \pm 1.2$ & $0.3 \pm 0.5$ & 27 \\
\hline $2.1-2.5$ & 33 & $9.8 \pm 4.8$ & $1.5 \pm 1.0$ & $0.2 \pm 0.4$ & 17 \\
\hline $2.6-3.0$ & 50 & $12.8 \pm 4.8$ & $1.5 \pm 1.0$ & $0.8 \pm 1.0$ & 50 \\
\hline
\end{tabular}

diplokaryotic and bi-nucleate forms because of the difficulty in getting central sections through both nuclei (Table 3). The diplokaryon of NZ B. exitiosa was similar in size to the bi-nucleate forms in Argentinian oysters, but had a higher N:C ratio, haplosporogenesis and lipid droplets. Haplosporosome numbers were higher in NZ and Argentinian B. exitiosa and Chilean Bonamia sp. than in B. ostreae, but haplosporogenesis was more prevalent in NZ B. exitiosa than in the other species, which showed similar levels of haplosporogenesis (Table 3).

With increase in size, each Bonamia showed a general increase in haplosporogenesis, number of mitochondrial profiles and lipid, except in Argentinian $B$. exitiosa and $B$. exitiosa from $C$. ariakensis (Table 4). The size groups of B. exitiosa in C. ariakensis, and more so Chilean Bonamia sp. and $B$. ostreae, were smaller than those of Argentinian and NZ $B$. exitiosa. In relation to seasonal differences, Bonamia from O. chilensis in NZ and Chile sampled at different times of the year showed that while NZ B. exitiosa showed a great increase in all parameters, Chilean Bonamia showed the same trend, but less so (Table 5).

Table 5. Comparison of Bonamia infecting Ostrea chilensis in New Zealand and Chile in relation to season. Data are means \pm SD. Prev.: prevalence

\begin{tabular}{|c|c|c|c|c|c|c|c|}
\hline \multirow[t]{2}{*}{ Date } & \multirow[t]{2}{*}{$\mathrm{n}$} & \multirow{2}{*}{$\begin{array}{l}\text { Size } \\
\left(\mu m^{2}\right)\end{array}$} & \multirow{2}{*}{$\begin{array}{c}\text { Haplosporo- } \\
\text { genesis at Golgi (\%) }\end{array}$} & \multirow{2}{*}{$\begin{array}{l}\text { No. of haplo- } \\
\text { sporosomes }\end{array}$} & \multirow{2}{*}{$\begin{array}{l}\text { Mitochondrial } \\
\text { profiles }\end{array}$} & \multicolumn{2}{|c|}{$\longrightarrow$ Lipid droplets } \\
\hline & & & & & & No. & Prev. (\%) \\
\hline \multicolumn{8}{|l|}{ New Zealand } \\
\hline Jan 1987 & 106 & $3.1 \pm 0.4$ & 39 & $15 \pm 7$ & $3 \pm 2$ & $0.7 \pm 0.9$ & 44 \\
\hline Apr 1990 & 61 & $3.0 \pm 0.4$ & 44 & $21 \pm 9$ & $4 \pm 2$ & $1.1 \pm 1.5$ & 56 \\
\hline Jun-Jul 1990 & 109 & $3.5 \pm 0.7$ & 85 & $37 \pm 18$ & $7 \pm 3$ & $1.1 \pm 0.5$ & 48 \\
\hline Aug 1990 & 147 & $4.3 \pm 0.6$ & 82 & $58 \pm 24$ & $9 \pm 4$ & $2.1 \pm 2.0$ & 73 \\
\hline \multicolumn{8}{|l|}{ Chile } \\
\hline Mar 2005 & 11 & $2.0 \pm 0.3$ & 36 & $12 \pm 7$ & $2 \pm 1$ & $0.3 \pm 0.5$ & 22 \\
\hline Apr 2005 & 24 & $2.2 \pm 0.5$ & 36 & $13 \pm 5$ & $1 \pm 1$ & $0.3 \pm 0.6$ & 28 \\
\hline May 2005 & 20 & $2.2 \pm 0.4$ & 59 & $11 \pm 6$ & $2 \pm 1$ & $0.2 \pm 0.4$ & 15 \\
\hline Jul 2005 & 49 & $2.2 \pm 0.7$ & 43 & $16 \pm 7$ & $3 \pm 2$ & $0.4 \pm 0.9$ & 30 \\
\hline Aug 2005 & 10 & $2.4 \pm 0.6$ & Poor fixation & Poor fixation & Poor fixation & Poor fixation & Poor fixation \\
\hline
\end{tabular}




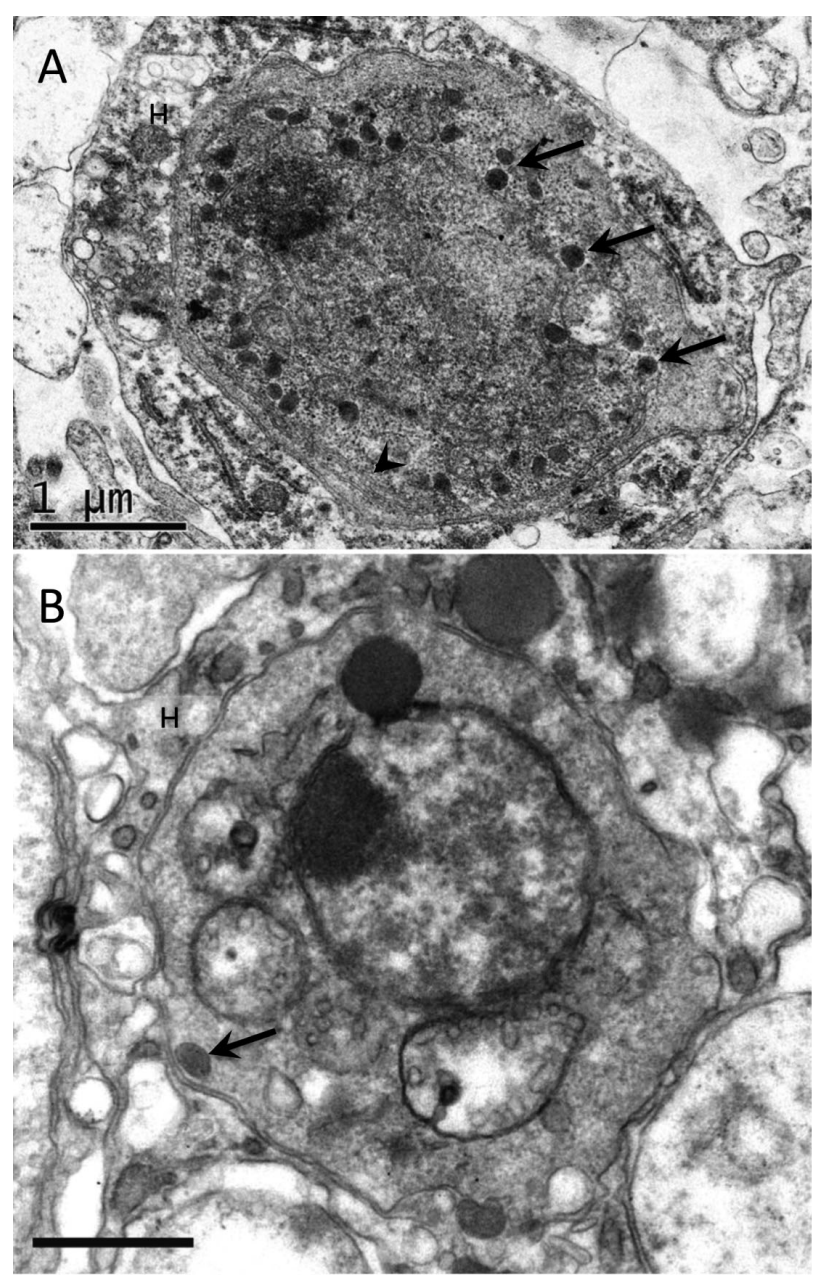

Fig. 1. Uni-nucleate stages of Bonamia exitiosa in (A) Ostrea edulis from Spain and (B) Crassostrea ariakensis from the USA. Host haemocyte cytoplasm indicated in both cases $(\mathrm{H})$ to mark the exterior of the $B$. exitiosa cells. Note the widely varying abundance of haplosporosomes (arrows), and the parallel arrays of smooth endoplasmic reticulum (arrowhead) in (A). Both scale bars $=1 \mu \mathrm{m}$

\section{DISCUSSION}

The problem with comparative ultrastructural studies on congeneric undescribed species, as in molecular studies showing DNA sequence divergence among such species, is deciding how much difference constitutes a separate species. While molecular studies reveal genotypes and are quantifiable in base transitions, ultrastructural studies reveal phenotypes which may be subject to many variables. These include host factors such as the species concerned, its age, physiological state, reproductive state and the presence of other infections (Hine 2002), environmental factors such as water temperature and salinity (Audemard et al. 2008, Carnegie et al. 2008), and methods of sam-
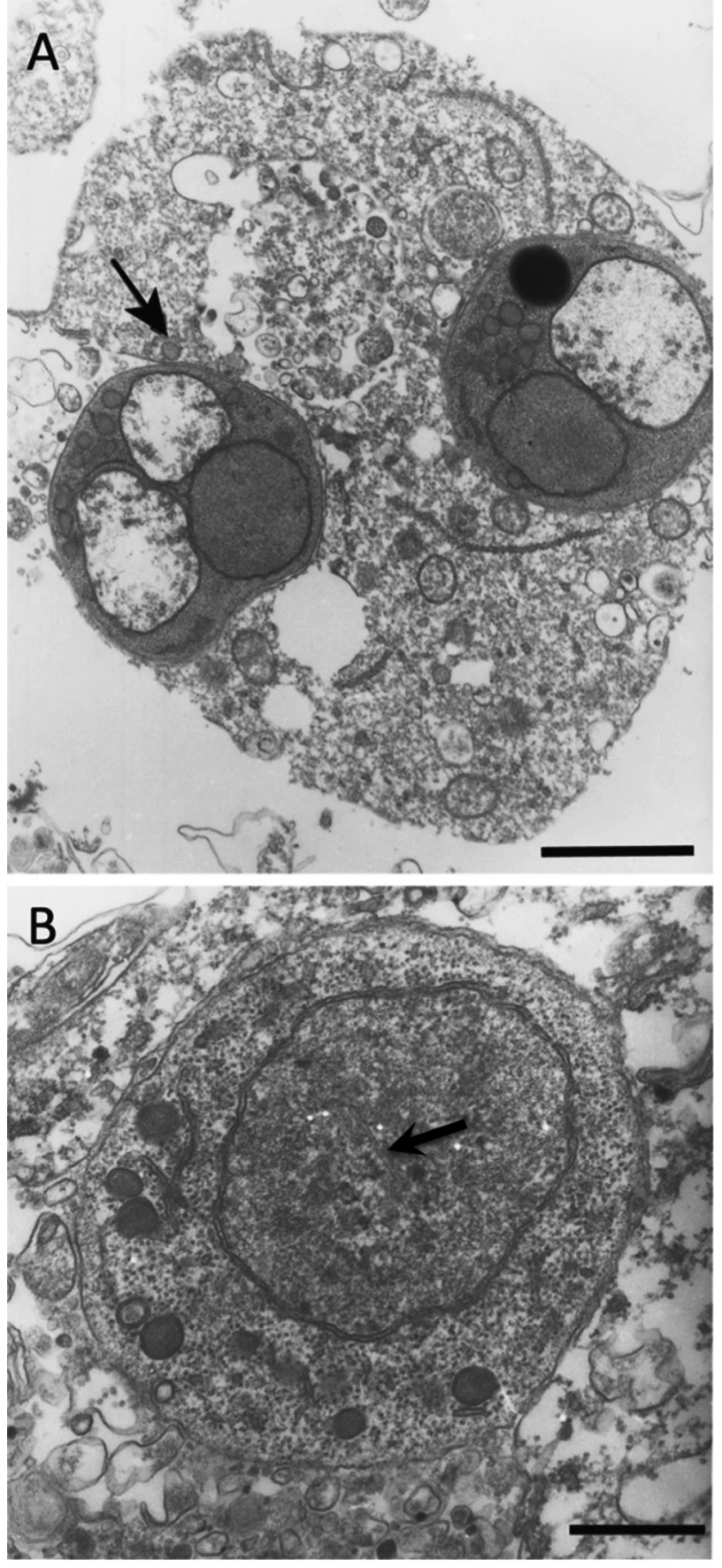

Fig. 2. Bonamia ostreae uni-nucleate stages in Ostrea edulis. (A) Low-power image of 2 cells infecting a single haemocyte. Note the displacement of $B$. ostreae nucleus to cell periphery, a common observation and distinct trait of this Bonamia species. Note also an extracellular haplosporosome (arrow), present along with numerous cytoplasmic haplosporosomes. Scale bar $=1 \mu \mathrm{m}$. (B) High-power image of a single $B$. ostreae cell. Note again the abundant haplosporosomes, with smooth endoplasmic reticulum also displayed along with an intranuclear microtubule (arrow). Scale bar $=$ $0.5 \mu \mathrm{m}$ 

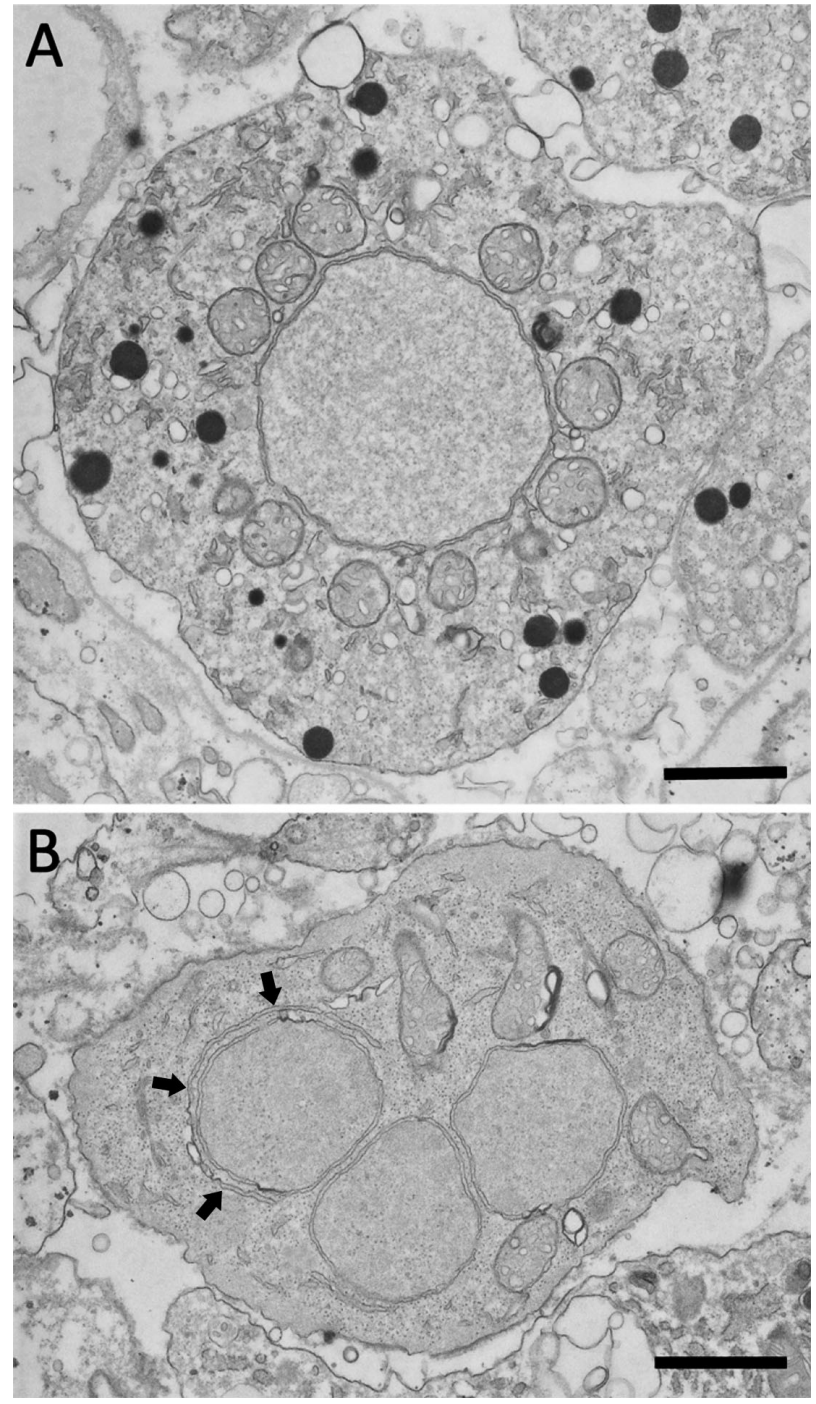

Fig. 3. Vegetative stages of Bonamia perspora in Ostrea stentina from the USA. (A) Uni-nucleate stage. (B) Small trinucleate plasmodium. Note the abundant mitochondria, particularly closely apposed to the nucleus in (A), the long stretch of endoplasmic reticulum head (arrows) in (B), and the general paucity of haplosporosomes. Dark bodies in (A) are lipid bodies. Both scale bars $=1 \mu \mathrm{m}$

pling, fixation and post-fixation. Parasite factors, such as the stages present at the time of sampling, which may be seasonal (Hine 1991a,b), the physiological state of the parasite and possible plasticity of life cycles, have also to be considered. In the latter case, although a spore stage is not known for Bonamia exitiosa, it does not necessarily mean that spores may not be formed under certain environmental conditions.

Interpretation of the ultrastructural features of Bonamia spp. must take these variables into account. These features fall into 3 groups: parasite metabolism, haplosporogenesis, and sporogony, the latter

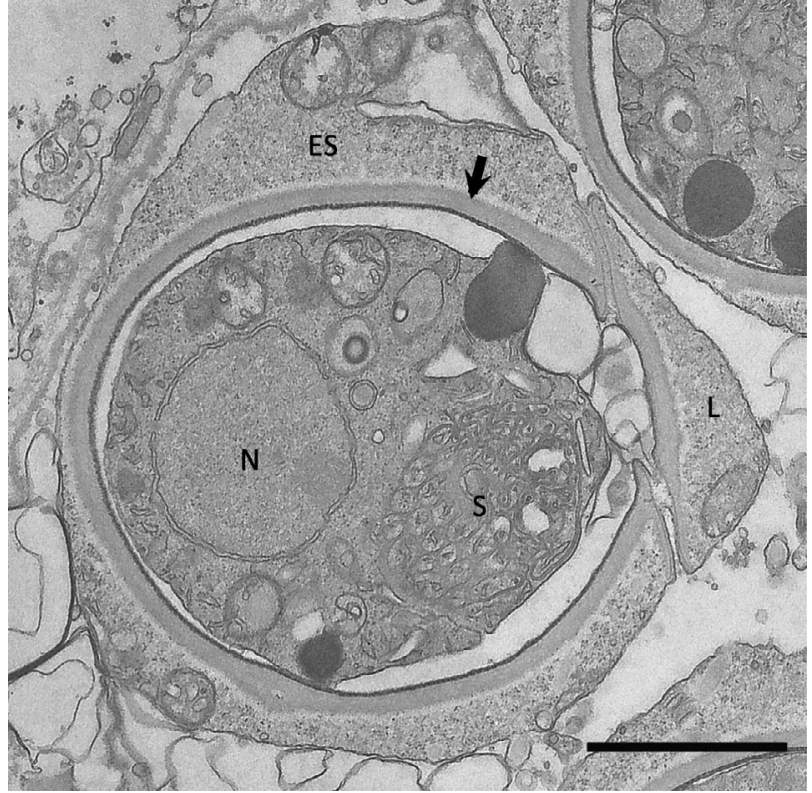

Fig. 4. Prespore of Bonamia perspora in Ostrea stentina from the USA. Note the developing wall (arrow), with epispore cytoplasm (ES) still present, and the well-defined lid (L), nucleus (N) and spherule (S). Scale bar $=1 \mu \mathrm{m}$

only being known in B. perspora. The metabolic state of the parasite is indicated by the mitochondria, lipid droplets and endoplasmic reticulum, which are most obvious in the development from a small intracellular uni-nucleate early stage to the large extracellular amoeboid feeding stage with large amounts of lipid, mitochondria and parallel arrays of endoplasmic reticulum in NZ B. exitiosa (see Hine \& Wesney 1994a). High lipid content was linked to season and development in the lipid-rich ovary in autumn to early winter (April to June; Hine 1991b). Seasonal annual development may also be linked to temperature in C. ariakensis infections (Carnegie et al. 2008). The production of lipid vesicles from, and acid hydrolases in, lipid droplets are associated with formation of a parasitophorous vacuole ( $\mathrm{PV}$; Hine \& Wesney 1994b), and $36 \%$ of Bonamia sp. in Crassostrea ariakensis were in PVs. Therefore, features reflecting metabolism are of little taxonomic value unless multiple variables are taken into account.

The taxonomic significance of haplosporogenesis, as indicated by NM-BG, TGN, INS, perinuclear granular material, and H-LBs (Hine \& Wesney 1992), is difficult to assess, as the function of haplosporosomes is unknown. Whilst it has been suggested that their glycoprotein coat and putative DNA core resembles the structure of viruses, their release associated with lysis of surrounding cells suggests a lytic function (Hine et al. 2002), but subsequent re-entry of cores in 
a haplosporidian infecting abalone (Hine et al. 2002) could represent horizontal gene transfer (Keeling \& Palmer 2008). The size and shape of haplosporosomes may be taxonomically important, but their plasticity in size and shape in relation to fixation is unknown. However, as haplosporosomes are the only structures quantifiable in size and number, they may be taxonomically important. If so, the uni-nucleate stages of NZ, Australian, C. ariakensis, Argentinian and Spanish B. exitiosa, and Chilean Bonamia are distinct from $B$. ostreae and B. perspora. These relationships are reflected in molecular phylogenies with NZ, Australian, $C$. ariakensis, Argentinian and European $B$. exitiosa closely related to the Chilean Bonamia (Hill et al. 2014, this DAO Special). Therefore, haplosporosome shape and size may be taxonomically important, but not haplosporosome number, as that is related to the size or developmental stage of the parasite. However, studies on Marteilia spp. (Paramyxea) (Villalba et al. 1993, Longshaw et al. 2001) suggest that haplosporosome shape and size may not be reliable as a taxonomic feature. Also, asporous Bonamia spp. are usually uni-nucleate and may be confused with the uni-nucleate stage of other haplosporidians, but most haplosporidian TEM studies have been on sporulation and the uni-nucleate stage is rarely described. The intra-haemocytic location of asporous Bonamia spp. is also unreliable because the vegetative stages of other haplosporidians may be phagocytosed by host haemocytes.

Uni-, bi- and multi-nucleate stages are known from C. ariakensis and probably Argentinian and Spanish $B$. exitiosa, and visually they were indistinguishable from each other and Australian B. exitiosa. Chilean Bonamia could be distinguished by the more osmiophilic membranes and NM-BG, but this could have been due to fixation and/or processing. NZ B. exitiosa also has a diplokaryotic stage, as does $B$. perspora, and the diplokaryon is a feature of multi-nucleate plasmodia of spore-forming haplosporidians, such as Urosporidium crescens, Haplosporidium louisiana, H. nelsoni and H. costale (Hine et al. 2009). Large NZ $B$. exitiosa in autumn and winter also contain cylindrical confronting cisternae (Hine \& Wesney 1992), as do Chilean Bonamia (Lohrmann et al. 2009), which have been attributed to an underlying viral infection (Hine \& Wesney 1992). As the NZ and Chilean Bonamia infect the same host $(O$. chilensis), but Chilean Bonamia are smaller with fewer, smaller haplosporosomes (Tables $1 \& 2$ ), Chilean Bonamia may have derived from NZ B. exitiosa but have been geographically isolated for sufficient time for the Chilean Bonamia to emerge as a distinct species. The Bona- mia from Australia (Corbeil et al. 2006), C. ariakensis (see Carnegie et al. 2006), Chile (Balseiro et al. 2006) and Spain (Abollo et al. 2008) have all been reported as B. exitiosa, but ultrastructurally, the Chilean Bonamia is similar to, but different from, $B$. exitiosa. Ultrastructure supports the identification of Australian, $C$. ariakensis, Argentinian and Spanish forms as B. exitiosa, as in molecular phylogenies (Hill et al. 2010, 2014). They appear more similar to each other in the cycling of uni-nucleate and bi-nucleate stages, than to the multiple forms of NZ B. exitiosa, but this may be due to the smaller sample sizes taken on only 1 occasion. There is a possibility, however, that the type species, NZ B. exitiosa, is atypical of the species, or that it has an underlying viral infection indicated by its ultrastructure (Hine \& Wesney 1992).

When studying phenotypic traits of an intracellular protozoan parasite, it is necessary to consider that the ultrastructure observed may be mediated by the host, as is histopathology, and possibly life cycles. Organisms are parsimonious and do not evolve to produce forms or stages that are of no benefit or waste energy reserves. Bonamia spp. may simply normally cycle through uni-nucleate and bi-nucleate stages, as seen in B. ostreae and the C. ariakensis, Argentinian and Spanish B. exitiosa. NZ B. exitiosa targets abundant host ovarian lipids during the female $O$. chilensis spawning cycle, to form a large actively feeding uninucleate stage not reported from elsewhere. NZ $B$. exitiosa also forms diplokarya which are only known from spore-forming species, and therefore NZ B. exitiosa may sporulate as a survival strategy under limiting conditions, suggesting that Bonamia spp. may have plastic life cycles. For example, the spore-forming species $H$. armoricanum may be able to go through its life cycle without sporulating, as suggested by the large plasmodia but absence of spores in $O$. edulis from St Philibert, Brittany (Brehélin et al. 1982, Vivarès et al. 1982, Bonami et al. 1985).

In conclusion, the interpretation of ultrastructure has to take into account multiple variables mediated by the parasite, the host and the environment. While this study on ultrastructure supports molecular phylogenies in that $B$. exitiosa is ultrastructurally distinct from $B$. ostreae and $B$. perspora, it shows considerable variability in the ultrastructure of $B$. exitiosa in different host species. These phenotypic differences reflect not only the Bonamia species concerned, but also the inter-relationships of the parasites with their hosts and the circumstances under which they were fixed, and variables in fixation. In comparison with the precise genotypic characterisation of organisms in molecular phylogenies, TEM studies are impre- 
cise, and because of the many variables affecting the parasite, they are not often useful in identifying species. The ultrastructure of the Chilean Bonamia, in particular, does not adequately distinguish it from NZ B. exitiosa. However, while molecular studies can be used to classify the parasite and establish its phylogenetic affinities, they give no information on the structure of the parasite, its developmental stage, physiological state and its interactions with the host. Diagnosis should combine molecular techniques with, in the case of protists, ultrastructural characterisation. The latter must identify ultrastructural features of taxonomic, rather than physiological or developmental, importance. Consequently, for spore-forming haplosporidians, spore structure is most useful, but there is less certainty regarding non-sporous or prespore stages.

Acknowledgements. This study was partially funded by grant PICT-2007-1338 (ANPCyT-Argentina). This is Virginia Institute of Marine Science contribution number 3385.

\section{LITERATURE CITED}

Abollo E, Ramilo A, Casas SM, Comesaña P, Cao A, Carballal MJ, Villalba A (2008) First detection of the protozoan parasite Bonamia exitiosa (Haplosporidia) infecting flat oyster Ostrea edulis grown in European waters. Aquaculture 274:201-207

> Audemard C, Carnegie RB, Stokes NA, Bishop MJ, Peterson $\mathrm{CH}$, Burreson EM (2008) Effects of salinity on Bonamia sp. survival in the Asian oyster Crassostrea ariakensis. J Shellfish Res 27:535-540

Balouet G, Poder M, Cahour A (1983) Haemocytic parasitosis: morphology and pathology of lesions in the French flat oyster, Ostrea edulis L. Aquaculture 34:1-14

> Balseiro P, Conchas RF, Montes J, Gómez-León J, Novoa B, Figueras A (2006) Comparison of diagnostic techniques for the protozoan parasite Bonamia ostreae in flat oyster Ostrea edulis. Aquaculture 261:1135-1143

Berthe FCJ, Hine PM (2003) Bonamia exitiosa Hine et al., 2001 is proposed instead of $B$. exitiosus as the valid name of Bonamia sp. infecting flat oysters Ostrea chilensis in New Zealand. Dis Aquat Org 57:181

- Bishop MJ, Carnegie RB, Stokes NA, Peterson CH, Burreson EM (2006) Complications of a non-native oyster introduction: facilitation of a local parasite. Mar Ecol Prog Ser 325:145-152

Bonami JR, Vivarès CP, Brehélin M (1985) Étude d'une nouvelle haplosporidie parasite de l'huitre plate Ostrea edulis L.: morphologie et cytologie de différents stades. Protistologica 21:161-173

Bougrier S, Tigé G, Bachère E, Grizel H (1986) Ostrea angasi acclimatization to French coasts. Aquaculture 58: 151-154

Brehélin M, Bonami JR, Cousserans F, Vivarès CP (1982) Existence de formes plasmodiales vraies chez Bonamia ostreae parasite de l'huître plate Ostrea edulis. CR Hebd Seances Acad Sci 295:45-48
Burreson EM, Stokes NA, Carnegie RB, Bishop MJ (2004) Bonamia sp. (Haplosporidia) found in non-native oysters, Crassostrea ariakensis, in Bogue Sound, North Carolina. J Aquat Anim Health 16:1-6

Campalans M, Lohrmann KB (2009) Histological survey of four species of cultivated molluscs in Chile susceptible to OIE notifiable diseases. Rev Biol Mar Oceanogr 44: 561-569

> Carnegie RB, Cochennec-Laureau N (2004) Microcell parasites of oysters: recent insights and future trends. Aquat Living Resour 17:519-528

> Carnegie RB, Burreson EM, Hine PM, Stokes NA, Audemard C, Bishop MJ, Peterson PH (2006) Bonamia perspora n. sp. (Haplosporidia), a parasite of the oyster Ostreola equestris, is the first Bonamia species known to produce spores. J Eukaryot Microbiol 53:232-245

Carnegie RB, Stokes NA, Audemard C, Bishop MJ and others (2008) Strong seasonality of Bonamia sp. infection and induced Crassostrea ariakensis mortality in Bogue and Masonboro Sounds, North Carolina, USA. J Invertebr Pathol 98:335-343

> Carnegie RB, Hill KM, Stokes NA, Burreson EM (2014) The haplosporidian Bonamia exitiosa is present in Australia, but the identity of the parasite described as Bonamia (formerly Mikrocytos) roughleyi is uncertain. J Invertebr Pathol 115:33-40

> Cochennec-Laureau N, Reece KS, Berthe FCJ, Hine PM (2003) Mikrocytos roughleyi taxonomic affiliation leads to the genus Bonamia (Haplosporidia). Dis Aquat Org 54: 209-217

Corbeil S, Arzul I, Robert M, Berthe FCJ, Besnard-Cochennec N, Crane MSJ (2006) Molecular characterisation of an Australian isolate of Bonamia exitiosa. Dis Aquat Org 71:81-85

- Elston RA, Farley CA, Kent ML (1986) Occurrence and significance of bonamiasis in European flat oysters Ostrea edulis in North America. Dis Aquat Org 2:49-54

> Engelsma MY, Culloty SC, Lynch SA, Arzul I, Carnegie RB (2014) Bonamia parasites: a rapidly changing perspective on a genus of important molluscan pathogens. Dis Aquat Org 110:5-23

Farley CA, Wolf PH, Elston RA (1988) A long-term study of 'microcell' disease in oysters with a description of a new genus, Mikrocytos (g.n.) and two new species, Mikrocytos mackini (sp.n.) and Mikrocytos roughleyi (sp.n.). Fish Bull 86:581-593

Friedman CS, Perkins FO (1994) Range extension of Bonamia ostreae to Maine, U.S.A. J Invertebr Pathol 64:179-181

Friedman CS, McDowell T, Groff JM, Hollibaugh JT, Manzer D, Hedrick RP (1989) Presence of Bonamia ostreae among populations of the European flat oyster, Ostrea edulis Linné, in California, USA. J Shellfish Res 8:133-137

Grizel H, Comps M, Raguenes D, Leborgne Y, Tigé G, Martin AG (1983) Bilan des essais d'acclimatation d'Ostrea chilensis sur les côtes de Bretagne. Rev Trav Inst Pêches Marit 46:209-225

Hill KM, Carnegie RB, Aloui-Bejaoui N, Gharsalli RE, White DM, Stokes NA, Burreson EM (2010) Observation of a Bonamia sp. infecting the oyster Ostrea stentina in Tunisia, and a consideration of its phylogenetic affinities. J Invertebr Pathol 103:179-185

Hill KM, Stokes NA, Webb SC, Hine PM and others (2014) Phylogenetics of Bonamia parasites based on small-subunit and internal transcribed spacer region ribosomal DNA sequence data. Dis Aquat Org 110:33-54 
Hine PM (1991a) Ultrastructural observations on the annual infection pattern of Bonamia sp. in flat oysters Tiostrea chilensis. Dis Aquat Org 11:163-171

Hine PM (1991b) The annual pattern of infection by Bonamia sp. in New Zealand flat oysters, Tiostrea chilensis. Aquaculture 93:241-251

Hine PM (1992) Ultrastructural and enzyme cytochemical observations on Bonamia sp. in oysters (Tiostrea chilensis), with a consideration of organelle function. Aquaculture 107:175-183

Hine PM (2002) Severe apicomplexan infection in the oyster Ostrea chilensis: a possible predisposing factor in bonamiosis. Dis Aquat Org 51:49-60

Hine PM, Wesney B (1992) Interrelationships of cytoplasmic structures in Bonamia sp. (Haplosporidia) infecting oysters Tiostrea chilensis: an interpretation. Dis Aquat Org 14:59-68

Hine PM, Wesney B (1994a) The functional cytology of Bonamia sp. (Haplosporidia) infecting oysters Tiostrea chilensis: an ultracytochemical study. Dis Aquat Org 20: 207-217

> Hine PM, Wesney B (1994b) Interaction of phagocytosed Bonamia sp. (Haplosporidia) with haemocytes of oysters Tiostrea chilensis. Dis Aquat Org 20:219-229

> Hine PM, Cochennec-Laureau N, Berthe FCJ (2001) Bonamia exitiosus n. sp. (Haplosporidia) infecting flat oysters Ostrea chilensis in New Zealand. Dis Aquat Org 47: 63-72

Hine PM, Wakefield S, Diggles BK, Webb VL, Maas EW (2002) Ultrastructure of a haplosporidian containing Rickettsiae, associated with mortalities among cultured paua Haliotis iris. Dis Aquat Org 49:207-219

Hine PM, Carnegie RB, Burreson EM, Engelsma MY (2009) Inter-relationships of haplosporidians deduced from ultrastructural studies. Dis Aquat Org 83:247-256

Keeling PJ, Palmer JD (2008) Horizontal gene transfer in eukaryotic evolution. Nat Rev Genet 9:605-618

Kroeck MA (2010) Gross signs and histopathology of Ostrea puelchana infected by a Bonamia exitiosa-like parasite (Haplosporidia). Dis Aquat Org 89:229-236

Kroeck MA, Montes J (2005) Occurrence of the haemocyte parasite Bonamia sp. in flat oysters Ostrea puelchana farmed in San Antonio Bay (Argentina). Dis Aquat Org 63:231-235

Editorial responsibility: Stephen Feist, Weymouth, UK
Kroeck MA, Semenas L, Morsan EM (2008) Epidemiological study of Bonamia sp. in the native flat oyster, Ostrea puelchana from San Matías Gulf (NW Patagonia, Argentina). Aquaculture 276:5-13

> Lohrmann KB, Hine PM, Campalans M (2009) Ultrastructure of Bonamia sp. in Ostrea chilensis in Chile. Dis Aquat Org 85:199-208

Longshaw M, Feist SW, Matthews RA, Figueras A (2001) Ultrastructural characterisation of Marteilia species (Paramyxea) from Ostrea edulis, Mytilus edulis and Mytilus galloprovincialis in Europe. Dis Aquat Org 44: 137-142

Lynch SA, Abollo E, Ramilo A, Cao A, Culloty SC, Villalba A (2010) Observations raise the question if the Pacific oyster, Crassostrea gigas, can act as either a carrier or a reservoir for Bonamia ostreae or Bonamia exitiosa. Parasitology 137:1515-1526

Marty GD, Bower SM, Clarke KR, Meyer G and others (2006) Histopathology and real-time PCR for detection of Bonamia ostreae in Ostrea edulis cultured in western Canada. Aquaculture 261:33-42

Narcisi V, Arzul I, Cargini D, Mosca F and others (2010) Detection of Bonamia ostreae and B. exitiosa (Haplosporidia) in Ostrea edulis from the Adriatic Sea (Italy). Dis Aquat Org 89:79-85

Pascual M, Martin AG, Zampatti E, Coatanea D, Defossez J, Robert R (1991) Testing of the Argentina oyster, Ostrea puelchana in several French oyster farming sites. ICES Council Meeting Papers. ICES CM 1991/K:30. ICES, Copenhagen

Pichot Y, Comps M, Tigé G, Grizel H, Rabouin MA (1979) Recherches sur Bonamia ostreae gen. n., sp. n., parasite nouveau de l'huitre plate Ostrea edulis. Rev Trav Inst Pêches Marit 43:131-140

> Villalba A, Mourelle SG, López MC, Carballal MJ, Azevedo C (1993) Marteiliasis affecting cultured mussels Mytilus galloprovincialis of Galicia (NW Spain). I. Etiology, phases of the infection, and temporal and spatial variability in prevalence. Dis Aquat Org 16: $61-72$

Vivarès CP, Brehélin $M$, Cousserans F, Bonami JR (1982) Mise en evidence d'une nouvelle Haplosporidie parasite de l'huitre plate Ostrea edulis L. CR Acad Sci 295: $127-130$

Submitted: April 4, 2013; Accepted: March 20, 2014 Proofs received from author(s): July 11, 2014 